\title{
Effect of Vanadium and Titanium on Desulfurization of CaO Slag in Liquid Iron
}

\author{
Biwen Yang ${ }^{1} \mathbb{C}$, Bo Song ${ }^{1, *}$, Longfei $\mathrm{Li}^{1}$ and Liang Chen ${ }^{2}$ \\ 1 School of Metallurgical and Ecological Engineering, University of Science and Technology Beijing, \\ Beijing 100083, China; ybwtx0807@163.com (B.Y.); aifei_0105@126.com (L.L.) \\ 2 State Key Laboratory of Vanadium and Titanium Resources Comprehensive Utilization, PanGang Group \\ Research Institute Co., Ltd., Panzhihua 617000, China; chenliang83916@163.com \\ * Correspondence: songbo@metall.ustb.edu.cn; Tel.: +86-130-0122-7018
}

Received: 15 October 2019; Accepted: 15 November 2019; Published: 19 November 2019

\begin{abstract}
The possibility of vanadium and titanium participating in the $\mathrm{CaO}$ desulfurization reaction has been evaluated. The desulfurization products of $\mathrm{CaO}$ which were added to liquid iron containing vanadium-titanium in lab conditions were observed. At the early stage of adding $\mathrm{CaO}$, titanium and sulfur ware agglomerated on the surface of $\mathrm{CaO}$ particles. The particles were composed of $\mathrm{CaO}$, $\mathrm{TiO}_{2}$, and $\mathrm{CaS}$. However, vanadium oxide was not detected. It was proposed that the titanium rather than the vanadium could react with $\mathrm{CaO}$ and sulfur. The desulfurization kinetics experiment showed that the high titanium content in liquid iron reduced desulfurization velocity, while vanadium had little effect on the desulfurization. The reason for this was that the $\mathrm{TiO}_{2}$ which surrounded the $\mathrm{CaO}$ particle impeded the mass transfer of sulfur. The vanadium and titanium had a little influence on the final sulfur content of $\mathrm{CaO}$ desulfurization. The theoretical discussion of these phenomena was carried out. The controlling reaction of final sulfur content was $(\mathrm{CaO})+[\mathrm{S}]+[\mathrm{C}]=(\mathrm{CaS})+\mathrm{CO}(\mathrm{g})$.
\end{abstract}

Keywords: hot metal desulfurization; vanadium; titanium; desulfurization reactions; thermodynamics and kinetics

\section{Introduction}

Before entering the steel-making converter, the hot metal desulfurization process is essential for the production of low sulfur steel and ultralow sulfur steel, which contributes to reducing the burden of blast furnace (BF) desulfurization and production cost, as well as improving production capacity [1-3]. Due to the unique properties of vanadium-titanium magnetite in Panzhihua, the molten iron should be subjected to desulfurization pretreatment and vanadium recovery before entering the steel-making converter. Vanadium recovery is a process whereby vanadium is oxidized by blowing oxygen at lower temperature (1536-1692 K) in the converter, forming a vanadium-containing slag. This slag is called vanadium slag. The statistics data of the steel plant show that this molten iron not only contains some vanadium (0.24-0.36 wt. \%) and titanium (0.08-0.31 wt. \%), but also has the characteristics of high sulfur content (0.036-0.136 wt. \%), low temperature (1480-1605 K), and poor fluidity (1-5 Pa.s of viscosity). According to the sequence of desulfurization and vanadium extraction, two processes have been proposed, namely, "blast furnace ironmaking $\rightarrow$ hot metal desulfurization $\rightarrow$ vanadium recovery $\rightarrow$ converter steelmaking" process and "blast furnace ironmaking $\rightarrow$ vanadium recovery $\rightarrow$ semi-steel desulfurization $\rightarrow$ converter steelmaking" process. The difference between the two processes is mainly desulfurization pretreatment. After vanadium extraction in the converter, the molten iron is called semi-steel. The temperature of the semi-steel increases about $100 \mathrm{~K}$. The contents of silicon, manganese, vanadium, and titanium of the semi-steel are extremely low, and the content of carbon decreases slightly. The components of desulfurizer are different for the two processes. The desulfurizer of the 
former process has a lower magnesium content than that of the latter process. The results of steel plant surveys show that the desulfurization effect of the latter process is better than that of the former process. The latter process has less final sulfur content and resulfurization, as well as higher utilization rate of desulfurizing agent [4].

However, the effect of vanadium and titanium on desulfurization is still not clear [5]. The study on the reaction of sulfur and titanium was proposed by Donahue, Wen, and Cheng [6-8]. They conclude that titanium could react with sulfur to form TiS. Moreover, the desulfurization ability of titanium has not been investigated under this condition. Visser et al. [9] suggest that $\mathrm{Ti}(\mathrm{C}, \mathrm{N})$ from BF can be used as the core of MgS. However, the proportion of $\mathrm{Ti}(\mathrm{C}, \mathrm{N})$ in those cores is not clarified. Wen et al. [7] propose that vanadium and titanium increase the viscosity of hot metal and have adverse effects on the desulfurization. Bouchard et al. [10] suggest the final sulfur decreases with the concentration of titanium.

These works on desulfurization mainly focus on the behavior of desulfurizer entering hot metal. There are few studies on the role of top slag in pre-desulfurization. Therefore, the purpose of this paper is to investigate the effects of laboratory-scale desulfurization experiments by adding $\mathrm{CaO}$. In the light of the actual production conditions, vanadium slag is used in the experiment. The effect of vanadium and titanium on $\mathrm{CaO}$ desulfurization in liquid iron is analyzed, and the role of top slag in desulfurization pretreatment is described. The thermodynamics and kinetics of desulfurization processes are discussed in terms of the results of the experiments.

\section{Experimental}

\subsection{Setup}

To study the reaction mechanisms and effectiveness of vanadium-titanium on desulfurization with $\mathrm{CaO}$ addition, an experimental device was established. To this end, it is necessary to skillfully perform loading and sampling to ensure stable experimental conditions.

A high-temperature furnace heated by silicon molybdenum rods is shown in Figure 1. The furnace was controlled with a proportional integral differential (PID) controller using a thermocouple (Pt-6\%Rh/Pt-30\%Rh). The heating elements were six U-shaped silicon molybdenum rods, which were evenly distributed along the furnace tube and were connected in series. The size of the furnace tube was $\Phi 60 \mathrm{~mm} \times 750 \mathrm{~mm}$. The length of the constant temperature zone was $100 \mathrm{~mm}$, and the temperature variation was $\pm 2 \mathrm{~K}$. Ar-gas at the bottom entered the furnace tube to protect the liquid iron from oxidation. The firebrick at the top of the furnace tube could be taken out when loading and sampling.

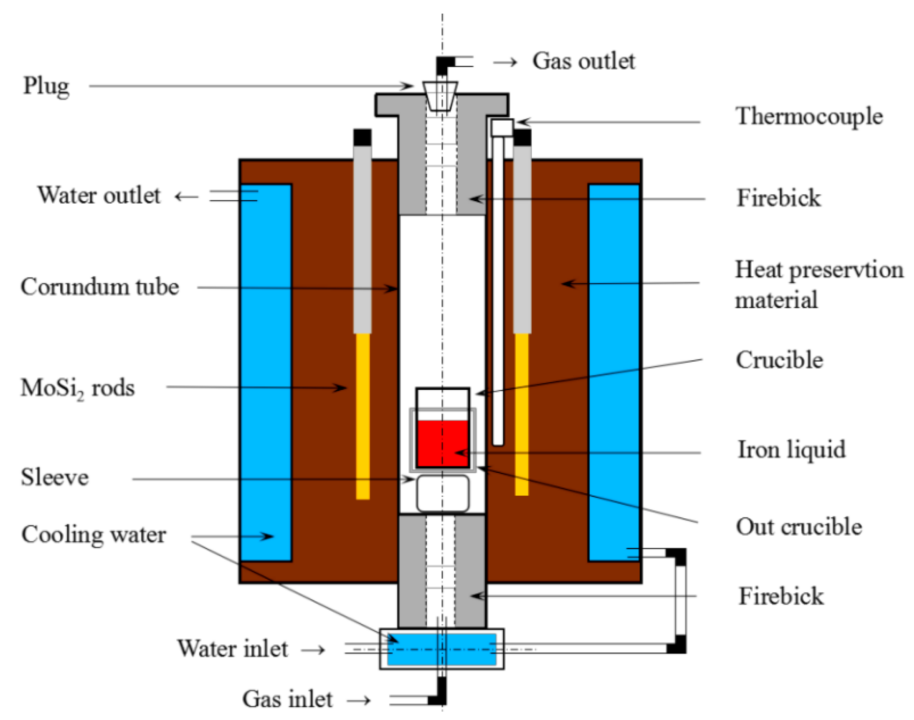

Figure 1. The experimental setup. 


\subsection{Materials}

In order to eliminate the interference of other elements, this experiment used pure iron carburizing to obtain liquid iron, with the addition of titanium powder, ferrovanadium, and ferrous sulfide. The slag consisting of vanadium slag and $\mathrm{CaO}$ was placed in a muffle furnace for eight hours at $1173 \mathrm{~K}$ before being weighed. Vanadium slag was provided by PanGang Group. Other chemicals that were purchased are listed in Tables 1 and 2.

Table 1. Materials used for desulfurization experiment.

\begin{tabular}{cc}
\hline Chemical & Purity/(wt. \%) \\
\hline Pure iron & 99.8 \\
Titanium powder & 99.0 \\
FeV50 $^{1}$ & 96.5 \\
$\mathrm{FeS}_{\mathrm{x}}{ }^{2}$ & 85.0 \\
$\mathrm{CaO}$ & 98.0 \\
$\mathrm{Ar}$ & 99.9
\end{tabular}

152.26 mass $\%$ of vanadium, ${ }^{2} 47.67$ mass $\%$ of sulfur, 43.68 mass $\%$ of ferrum, and 7.89 mass $\%$ of oxygen.

Table 2. Compositions of vanadium slag. (wt. \%).

\begin{tabular}{ccccccccc}
\hline $\mathrm{CaO}$ & $\mathrm{SiO}_{2}$ & $\mathrm{MgO}$ & $\mathrm{Al}_{2} \mathbf{O}_{3}$ & $\mathbf{V}_{\mathbf{2}} \mathrm{O}_{3}$ & $\mathrm{TiO}_{2}$ & $\mathrm{MnO}$ & $\mathbf{T F e}$ & $\mathbf{S}$ \\
\hline 10.53 & 23.82 & 6.01 & 6.94 & 8.75 & 10.52 & 4.03 & 24.94 & 0.71 \\
\hline
\end{tabular}

\subsection{Procedure}

As shown in Figure 2, the materials were kept in a graphite crucible. There was a handle made of molybdenum wire, tied on the graphite crucible. Thus, the graphite crucible could be taken out and put in with a molybdenum-made tool. The corundum crucible played a protective role in preventing liquid iron from leaking out. A pure iron rod was used to add the powder into the liquid iron. The powder was wrapped in a pure iron slice at the bottom of the rod.

The alumina tube was flushed with Ar-gas ( $0.5 \mathrm{~L} / \mathrm{min}), 6 \mathrm{~h}$ before the experiment. The gas was injected throughout the whole experiment. All the experiments were carried out at $1623 \mathrm{~K}$.

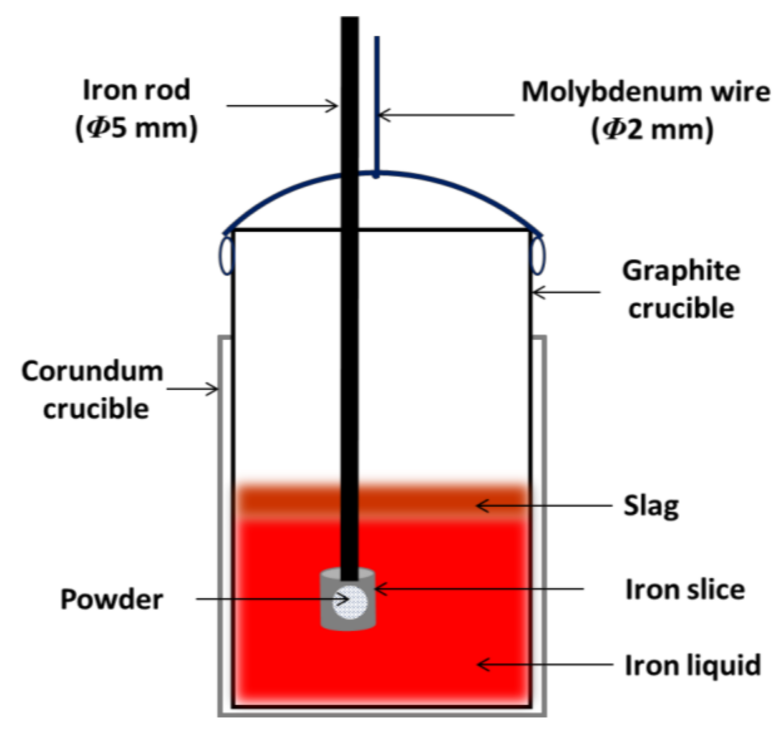

Figure 2. Diagram of crucibles and raw materials.

To study the effects of vanadium and titanium on final sulfur content, $100.0 \pm 0.1 \mathrm{~g}$ of pure iron, $0.3 \mathrm{~g}$ of FeS, and different amounts of ferrovanadium and titanium powder were mixed. Considering 
the mass ratio of $2 \mathrm{wt}$. \% of slag to hot metal in desulfurization pretreatment, $2.0 \pm 0.1 \mathrm{~g}$ of vanadium slag and $0.8 \mathrm{~g}$ of $\mathrm{CaO}$ for the desulfurization reaction were mixed and put on the top of the pure iron. When the temperature was heated up to $1623 \mathrm{~K}$, the graphite crucible was put into the corundum crucible. The metal melted in $20 \mathrm{~min}$ and was then kept at the uniform temperature for $2 \mathrm{~h}$. After the reaction was completed, the graphite crucible was taken out and placed in water to cool, preventing water from entering the crucible during the cooling process. The sample solidified within $10 \mathrm{~s}$.

To study the effects of vanadium and titanium on desulfurization products and velocity, $200 \pm 0.1 \mathrm{~g}$ of pure iron powder were added to the graphite crucible. When the temperature raised to $1623 \mathrm{~K}$, the graphite crucible was put in the corundum crucible. The metal melted in $30 \mathrm{~min}$. Subsequently, $0.9 \mathrm{~g}$ of ferrovanadium and $0.5 \mathrm{~g}$ of titanium powder were added into the liquid iron. Then, the liquid iron was stirred by the pure iron rod. After $5 \mathrm{~min}$, ferrous sulfur was added. After $2 \mathrm{~h}$, sufficient $\mathrm{CaO}$ powder was added. One minute later, the graphite crucible was quickly taken out and placed in cooling water to prevent the water from entering the crucible. A center sample and a top sample were made. In addition, three crucibles were taken and sampled at 1, 30, 60, 90, and 120 min after adding $1.6 \mathrm{~g}$ of $\mathrm{CaO}$ powder and $4.0 \mathrm{~g}$ of vanadium slag. One milliliter of liquid metal was taken out each time. The sample was rapidly cooled in water. The compositions of the liquid iron are shown in Table 3. The sampling tool that is shown in Figure 3 was a quartz tube with a syringe.

Table 3. Compositions of the liquid iron before reaction (wt. \%).

\begin{tabular}{ccccc}
\hline No. & C & S & V & Ti \\
\hline I & 2.4 & 0.17 & 0.01 & 0.02 \\
II & 2.6 & 0.17 & 0.02 & 0.24 \\
III & 2.4 & 0.16 & 0.19 & 0.03 \\
\hline
\end{tabular}

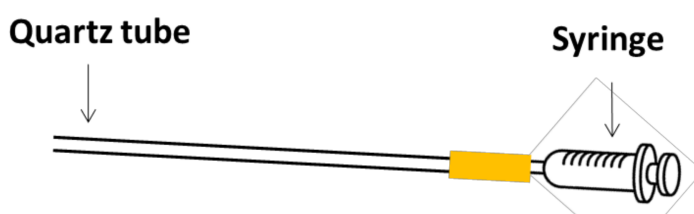

Figure 3. Diagram of sampling tool.

\subsection{Analysis}

The carbon concentration in the metal was analyzed by combustion instrumental measurement test method (ASTM E1019) and had a detection limit of $100 \mathrm{ppm}$. Sulfur analysis of the metal after the experiments was performed with combustion-infrared absorption test method (calibration with metal reference materials, ASTM E1019). It had a detection limit of $10 \mathrm{ppm}$. The contents of vanadium and titanium in the metal were analyzed by atomic absorption spectroscopy (AAS, AA-6800), and it had the same detection limit with carbon.

The slag composition was analyzed by an X-ray fluorescence spectrometer (XRF, 1800, Shimadzu, Japan).

The desulfurization products were observed by a JSM-6480LV scanning electron microscope (SEM, JEOL, Tokyo, Japan) with energy dispersive X-ray spectroscope (EDS, Noran System six, JEOL, Tokyo, Japan).

\section{Results}

Tables 4 and 5 present the experimental results after $2 \mathrm{~h}$ reaction. In order to determine the yield of sulfur, only pure iron and $\mathrm{FeS}$ were added in sample a, which had the same duration of constant temperature as the other samples. The result of the test shows that the yield of sulfur was above $98 \%$, which means that sulfur did not escape. 
For samples c-g, the contents of carbon and titanium were kept unchanged, and the content of vanadium was changed from $0.1 \%$ to $1.0 \%$. Similarly, samples $\mathrm{d}$ and $\mathrm{h}-\mathrm{k}$ were used to study the influence of titanium content. By comparison, vanadium and titanium were not added into the liquid iron of sample $b$. It is clearly seen that the carburizing amount was $1.65-2.30$ mass $\%$. The final sulfur content of all samples was about $0.06 \mathrm{wt}$. \%, except for sample e. This result was significantly higher than that of desulfurizer entering hot metal.

The same masses of $\mathrm{CaO}$ powder and vanadium slag were added in all samples. Except for $\mathrm{TiO}_{2}$, the composition of the slag after reaction changed little.

Table 4. Compositions of elements in liquid iron (wt. \%).

\begin{tabular}{cccccccc}
\hline Sample Name & $\mathbf{C}$ & $\mathbf{S}_{\text {addition }}$ & $\mathbf{S}_{\text {final }}$ & $\mathbf{V}_{\text {addition }}$ & $\mathbf{V}_{\text {final }}$ & $\mathbf{T i}_{\text {addition }}$ & $\mathbf{T i}_{\text {final }}$ \\
\hline $\mathrm{a}$ & 2.23 & 0.146 & 0.144 & - & - & - & - \\
$\mathrm{b}$ & 2.17 & 0.171 & 0.057 & - & - & - & - \\
$\mathrm{c}$ & 2.08 & 0.167 & 0.058 & 0.13 & 0.12 & 0.35 & 0.28 \\
$\mathrm{~d}$ & 2.12 & 0.175 & 0.059 & 0.41 & 0.42 & 0.29 & 0.24 \\
$\mathrm{e}$ & 1.65 & 0.167 & 0.081 & 0.55 & 0.51 & 0.34 & 0.31 \\
$\mathrm{f}$ & 2.30 & 0.174 & 0.061 & 0.85 & 0.84 & 0.35 & 0.27 \\
$\mathrm{~g}$ & 2.04 & 0.168 & 0.059 & 0.95 & 0.92 & 0.31 & 0.25 \\
$\mathrm{~h}$ & 2.23 & 0.165 & 0.058 & 0.35 & 0.36 & 0.06 & 0.04 \\
$\mathrm{i}$ & 2.21 & 0.166 & 0.060 & 0.40 & 0.37 & 0.56 & 0.48 \\
$\mathrm{j}$ & 2.16 & 0.152 & 0.060 & 0.42 & 0.39 & 0.69 & 0.53 \\
$\mathrm{k}$ & 2.11 & 0.157 & 0.065 & 0.35 & 0.33 & 0.98 & 0.86 \\
\hline
\end{tabular}

Table 5. Compositions of slag after desulfurization (wt. \%).

\begin{tabular}{cccccccccc}
\hline Sample Name & $\mathbf{C a O}$ & $\mathbf{S i O}_{\mathbf{2}}$ & $\mathbf{M g O}$ & $\mathrm{Al}_{\mathbf{2}} \mathbf{O}_{\mathbf{3}}$ & $\mathbf{V}_{\mathbf{2}} \mathbf{O}_{\mathbf{3}}$ & $\mathbf{T i O}_{\mathbf{2}}$ & $\mathbf{M n O}$ & $\mathbf{T F e}$ & $\mathbf{S}$ \\
\hline $\mathrm{a}$ & - & - & - & - & - & - & - & - & - \\
$\mathrm{b}$ & 31.19 & 17.14 & 4.32 & 4.99 & 6.30 & 7.22 & 2.90 & 13.54 & 4.40 \\
$\mathrm{c}$ & 30.91 & 16.79 & 4.23 & 4.89 & 6.16 & 10.38 & 2.85 & 13.12 & 4.13 \\
$\mathrm{~d}$ & 30.80 & 16.99 & 4.29 & 4.95 & 5.71 & 9.94 & 2.88 & 12.94 & 4.40 \\
$\mathrm{e}$ & 32.96 & 17.14 & 4.33 & 4.99 & 6.82 & 8.90 & 2.90 & 13.13 & 3.42 \\
$\mathrm{f}$ & 30.36 & 16.61 & 4.19 & 4.84 & 6.62 & 11.45 & 2.81 & 13.22 & 4.24 \\
$\mathrm{~g}$ & 30.84 & 16.76 & 4.23 & 4.88 & 7.19 & 10.39 & 2.84 & 12.97 & 4.12 \\
h & 31.78 & 17.23 & 4.35 & 5.02 & 5.79 & 8.36 & 2.91 & 13.03 & 4.16 \\
$\mathrm{i}$ & 30.86 & 16.66 & 4.20 & 4.85 & 6.63 & 11.48 & 2.82 & 13.21 & 4.01 \\
j & 30.14 & 16.34 & 4.12 & 4.76 & 6.00 & 14.64 & 2.76 & 13.07 & 3.48 \\
$\mathrm{k}$ & 30.69 & 16.64 & 4.19 & 4.84 & 5.60 & 13.68 & 2.81 & 13.15 & 3.54 \\
\hline
\end{tabular}

Figure 4 shows the change of sulfur content of the samples in Table 3 as a function of reaction time. The desulfurization rate of sample I with low content of vanadium and titanium is fastest, and the desulfurization velocity of sample II containing titanium is slowest. There is no significant difference in the final sulfur content among the three samples.

A small $\mathrm{CaO}$ particle (about $5 \mu \mathrm{m}$ ) in the center of the sample transformed to calcium sulfide in a short time, and is shown with high magnification in Figure 5. Sulfur penetrates into the center of the particles from the surface gradually, while vanadium and titanium do not accumulate on the surface. 


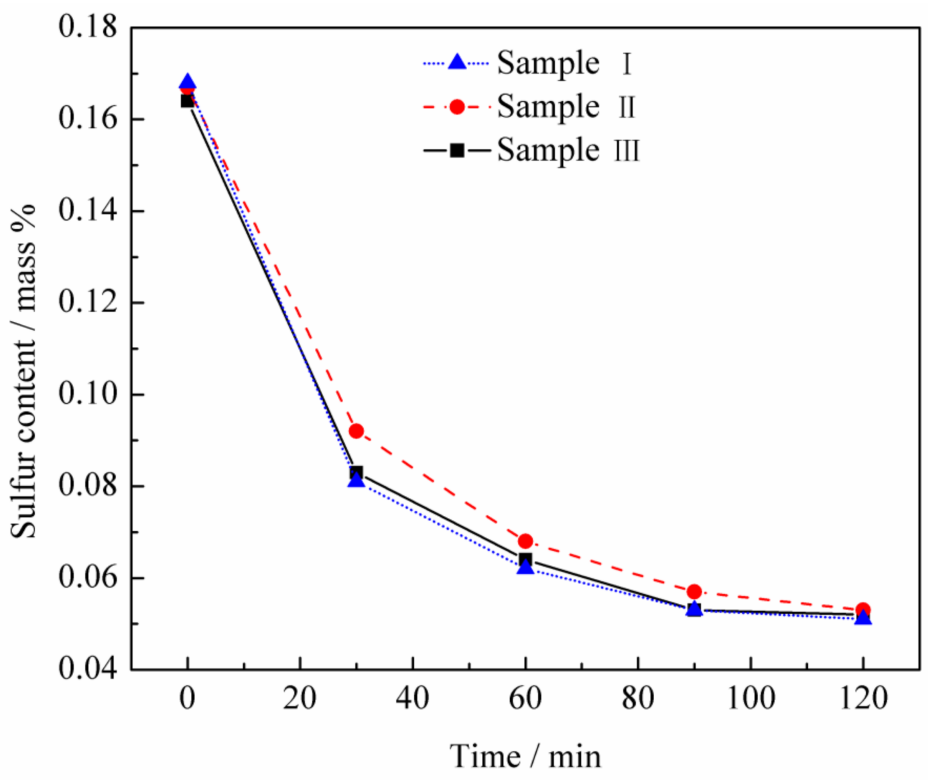

Figure 4. Sulfur content of the samples as a function of reaction time.
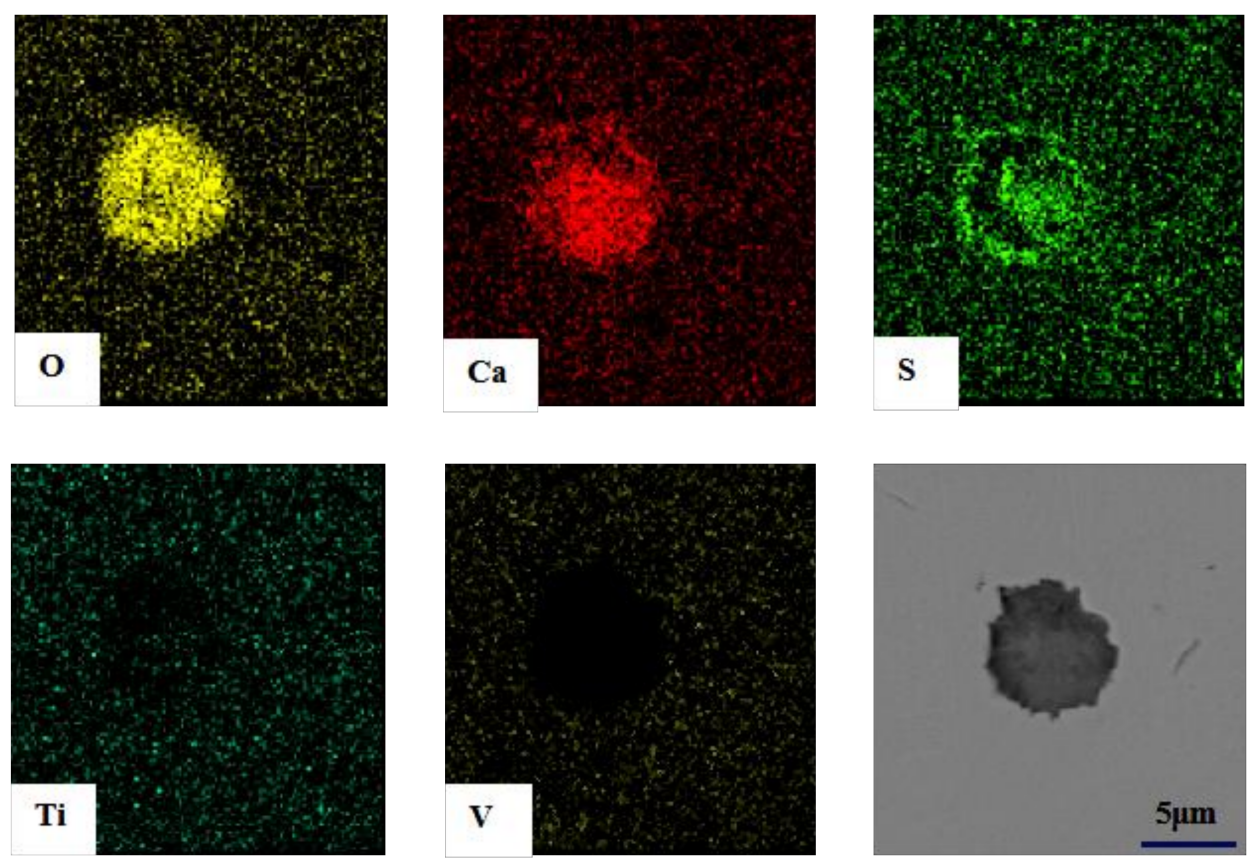

Figure 5. Element mappings showing $\mathrm{CaS}$ growth on $\mathrm{CaO}$ particle.

In Figure 6, the aggregation of sulfur and titanium occurs on the surface of the sheet-like $\mathrm{CaO}$ (about $100 \mu \mathrm{m}$ ). Additionally, the position of titanium appears to have the aggregation of sulfur, which indicates that the oxygen portion displaced by sulfur reacted with titanium to form an oxide of titanium attached to the core of $\mathrm{CaO}$. EDS analysis indicated the presence of $\mathrm{TiO}_{2}$. The result is very similar to silicon in liquid iron [11,12]. However, vanadium is not accumulated on the surface of $\mathrm{CaO}$. Compared with Figure 4, particles with small $\mathrm{CaO}$ size have little aggregation of titanium, and the presence of titanium is more easily found on a larger $\mathrm{CaO}$ powder. 

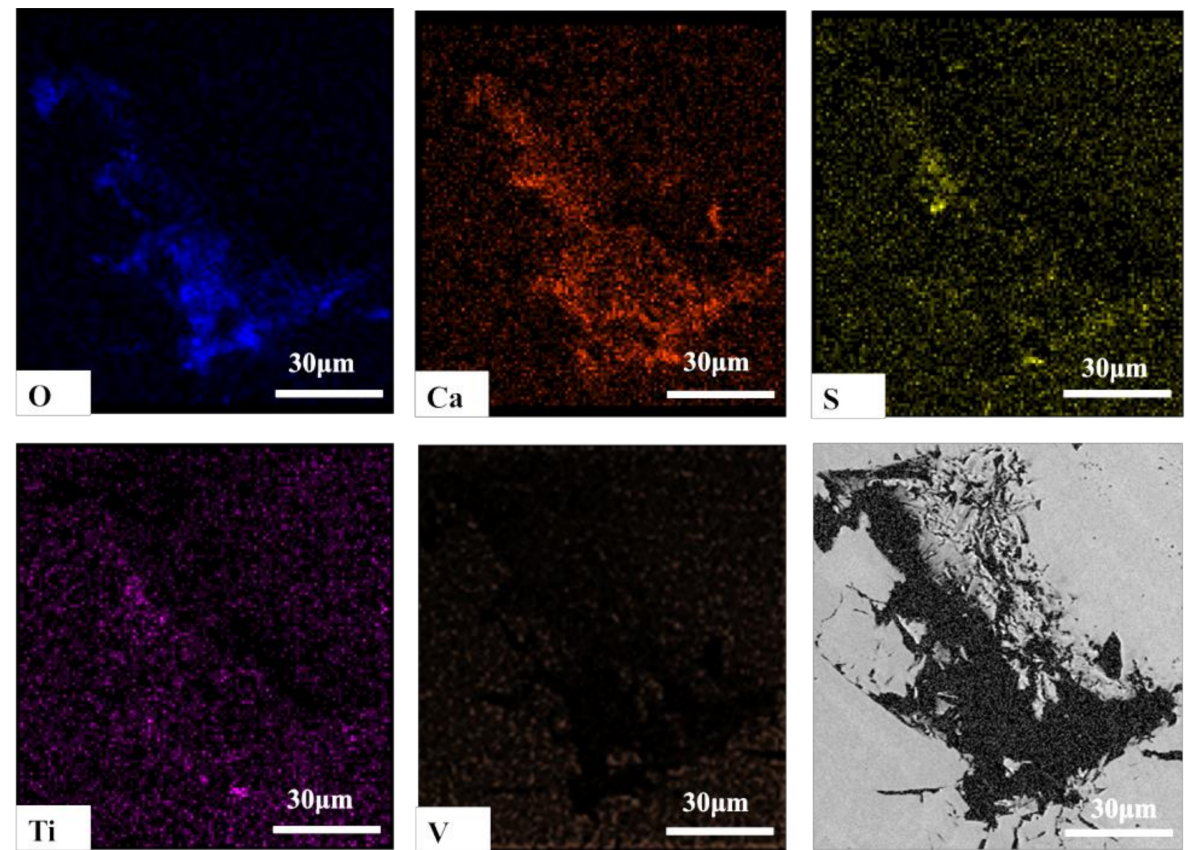

Figure 6. Agglomerate of $\mathrm{CaO}$ surrounded by $\mathrm{TiO}_{2}$ and $\mathrm{CaS}$.

Figure 7 shows the result of the slag, and the composition of each point is shown in Table 6. The unreacted $\mathrm{CaO}$ mixed with $\mathrm{CaS}$ and $\mathrm{TiO}_{2}$ on the surface of liquid iron, with a small amount of iron interposed there between, as shown in points 3 and 4 . The content of vanadium in the slag was extremely small.

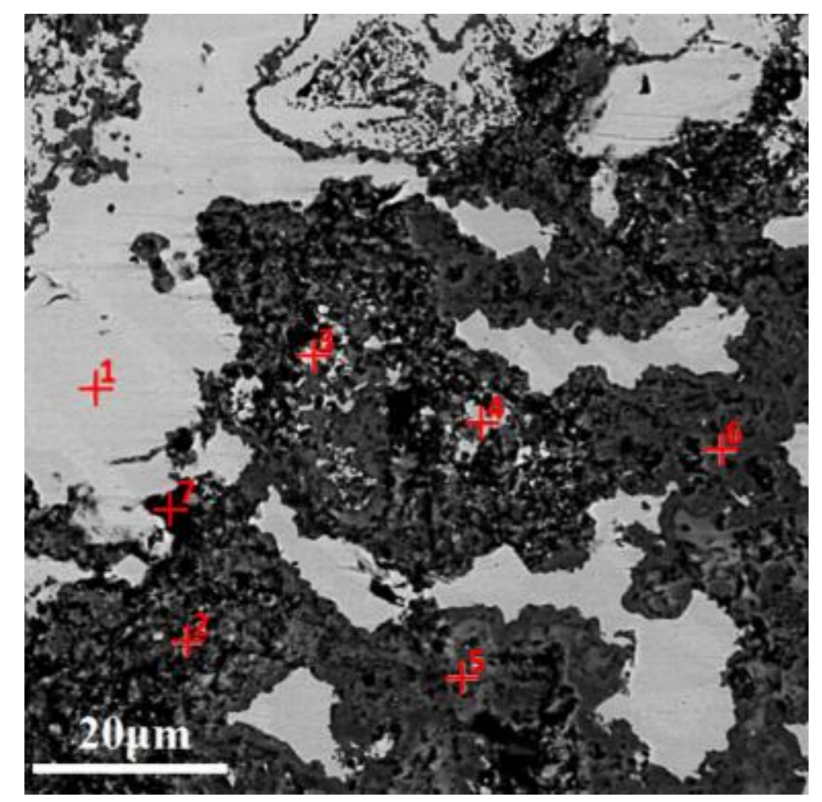

Figure 7. SEM images of the top sample. 
Table 6. EDS of each point in Figure 7 (wt. \%).

\begin{tabular}{ccccccc}
\hline No. & Fe & O & S & Ca & V & Ti \\
\hline 1 & 99.1 & 0.2 & 0.1 & 0.1 & 0.3 & 0.2 \\
2 & 11.4 & 20.5 & 9.7 & 42.3 & 3.5 & 12.6 \\
3 & 23.7 & 18.9 & 11.2 & 33.4 & 4.1 & 8.7 \\
4 & 23.7 & 20.5 & 14.3 & 26.9 & 2.1 & 12.5 \\
5 & 8.4 & 20.9 & 23.7 & 30.3 & 2.9 & 13.8 \\
6 & 6.9 & 22.1 & 15.7 & 34.2 & 2.2 & 18.9 \\
7 & 48.4 & 26.9 & 3.2 & 12.5 & 1.7 & 7.3 \\
\hline
\end{tabular}

\section{Discussion}

\subsection{Thermodynamic Perspective}

In the desulfurization process of $\mathrm{CaO}$, carbon vanadium and titanium in the liquid iron may participate in the reactions. Considering the difference in the ability of each element to react with oxygen, the possible desulfurization reactions are analyzed from Gibbs free energy, as shown in Figure 8 . The $\Delta G$ value is calculated by the following equation:

$$
\Delta G_{i}=\Delta G_{i}^{o}+R T \ln J_{i}
$$

In the calculation process, the activities of oxides (sulfides) are based on the mass fraction of the slag [13]. The activity coefficient of an element in liquid iron is calculated by the Wagner model as shown in the following formula $[14,15]$ :

$$
\lg f_{i}=\sum_{j=i}^{n}[j]_{\%} \times e_{i}^{j}
$$

where $f_{i}$ is the activity coefficient of component $i,[j]_{\%}$ is the mass percentage of component $j, e_{i}^{j}$ is the activity interaction coefficient of component $j$ on component $i$.

The activity interaction coefficients of carbon, sulfur, vanadium, and titanium are listed in Table 7. The data in the literature [16-18] were calculated according to the experimental results in the carbon-saturated iron liquid. The data in the literature [19-21] were obtained in the liquid steel with low sulfur, vanadium, and titanium contents. The activity interaction coefficient is suitable for the experimental conditions. The activity interaction coefficient decreases slightly with temperature [22-24]. This has little effect on the calculation result. The calculated value of activity coefficient is shown in Table 8.

Table 7. Activity interaction coefficient of the main elements.

\begin{tabular}{ccccc}
\hline Element & $\mathbf{S}$ & $\mathbf{C}$ & $\mathbf{V}$ & $\mathbf{T i}$ \\
\hline$e_{C}^{j}$ & $0.11(1623 \mathrm{~K})[16]$ & $0.20(1623 \mathrm{~K})[16]$ & $-0.054(1708 \mathrm{~K})[17]$ & $-0.052(1673 \mathrm{~K})[18]$ \\
$e_{T, i}^{j}$ & $-0.11(1873 \mathrm{~K})[19]$ & $-0.22(1673 \mathrm{~K})[18]$ & - & $0.023(1823 \mathrm{~K})[20]$ \\
$e_{S}^{j}$ & $-0.033(1623 \mathrm{~K})[17]$ & $0.29(1623 \mathrm{~K})[16]$ & $-0.016(1873 \mathrm{~K})[21]$ & $-0.072(1873 \mathrm{~K})[19]$ \\
$e_{V}^{j}$ & $-0.028(1873 \mathrm{~K})[21]$ & $-0.24(1708 \mathrm{~K})[17]$ & $0.015(1823 \mathrm{~K})[20]$ & - \\
\hline
\end{tabular}

Table 8. Activity coefficient of C, S, V, and Ti.

\begin{tabular}{cccccccccccc}
\hline Sample Name & $\mathbf{a}$ & $\mathbf{b}$ & $\mathbf{c}$ & $\mathbf{d}$ & $\mathbf{e}$ & $\mathbf{f}$ & $\mathbf{g}$ & $\mathbf{h}$ & $\mathbf{i}$ & $\mathbf{j}$ & $\mathbf{k}$ \\
\hline$f_{C}$ & - & 2.79 & 2.51 & 2.49 & 1.96 & 2.55 & 2.25 & 2.70 & 2.53 & 2.46 & 2.32 \\
$f_{S}$ & - & 4.24 & 3.79 & 3.89 & 2.79 & 4.29 & 3.60 & 4.33 & 3.97 & 3.80 & 3.49 \\
$f_{V}$ & - & 0.30 & 0.32 & 0.31 & 0.41 & 0.29 & 0.33 & 0.29 & 0.30 & 0.31 & 0.31 \\
$f_{T i}$ & - & 0.33 & 0.35 & 0.34 & 0.43 & 0.31 & 0.36 & 0.32 & 0.33 & 0.34 & 0.35 \\
\hline
\end{tabular}




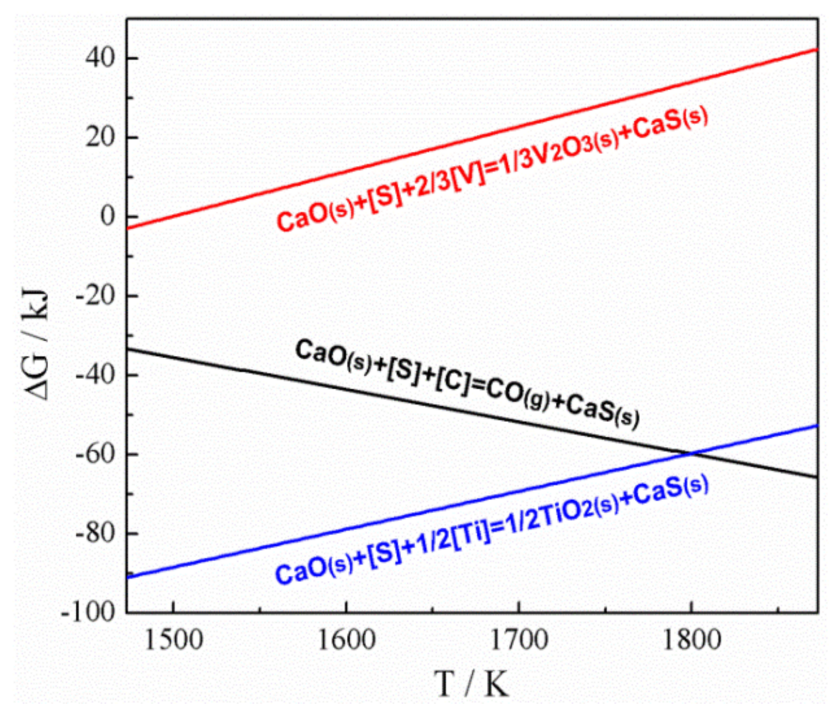

Figure 8. $\Delta G$ values with temperature.

The desulfurization reactions are likely to happen with titanium or carbon, except vanadium. The $\Delta G$ value of the reaction with carbon decreases with the temperature, while that of titanium is the opposite. The $\Delta G$ value of the reaction with titanium is lower than that of carbon at $1623 \mathrm{~K}$. The results in Figures 5 and 6 also demonstrate that carbon and titanium participate in the desulfurization reaction of $\mathrm{CaO}$.

According to the experimental results in Table 5, changes of vanadium and titanium have little effect on final sulfur content. The final sulfur content is calculated by:

$$
\begin{gathered}
(\mathrm{CaO})+[\mathrm{S}]+[\mathrm{C}]=\mathrm{CO}(\mathrm{g})+(\mathrm{CaS}) ; \Delta G_{\mathrm{C}}^{o}=86570-70.3 T[18] \\
{[S]_{\%}=\frac{P_{\mathrm{CO}}}{e^{-\Delta G_{\mathrm{C}}^{o} / R T}} \times \frac{a_{(\mathrm{CaS})}}{a_{(\mathrm{CaO})}} \times \frac{1}{[\mathrm{C}]_{\%} f_{\mathrm{C}} f_{S}}} \\
(\mathrm{CaO})+[\mathrm{S}]+1 / 2[\mathrm{Ti}]=1 / 2\left(\mathrm{TiO}_{2}\right)+(\mathrm{CaS}) ; \Delta G_{T i}^{o}=-232045+83.82 T[18] \\
{[S]_{\%}=\frac{1}{e^{-\Delta G_{T i}^{o} / R T}} \times \frac{1}{f_{S}} \times \frac{a_{(\mathrm{CaS})}}{a_{(\mathrm{CaO})}} \times\left(\frac{a_{\left(T i O_{2}\right)}}{[T i]_{\%} f_{T i}}\right)^{\frac{1}{2}}}
\end{gathered}
$$

where $P_{\mathrm{CO}}$ is the carbon monoxide partial pressure, $a_{(\mathrm{CaS})}$ is the activity of $\mathrm{CaS}$ in slag, $a_{(\mathrm{CaO})}$ is the activity of $\mathrm{CaO}$, and $a_{\left(\mathrm{TiO}_{2}\right)}$ is the activity of $\mathrm{TiO}_{2}$.

The calculated result is shown in Figure 9. Compared with the experimental values, the final sulfur content controlled by Reaction (3) is cogent, which means that the thermodynamic conditions of desulfurization have changed and titanium has not participated in the desulfurization of $\mathrm{CaO}$ at the later stage. In Figure 9a, sample data shows that the sulfur content is significantly higher than that of the other four groups, reaching $0.81 \%$. The reason is that the carbon content in this sample is relatively low with only 1.65 wt. \%.

Judging by Equations (4) and (6), the final sulfur content is proportional to the ratio of CaS activity to $\mathrm{CaO}$ activity in slag, whether it is carbon or titanium. For Reaction (5), the final sulfur content is also proportional to the ratio of titanium dioxide activity in slag and titanium activity in liquid iron. The results in Tables 3 and 4 indicate that the higher the content of titanium in liquid iron, the larger the amount of $\mathrm{TiO}_{2}$ in slag after desulfurization. The activity of $\mathrm{TiO}_{2}$ corresponds to that of the mass fraction. As $\mathrm{CaO}$ reacts with acidic oxides in slag to form complex oxides, such as $\mathrm{CaTiO}_{3}$, free $\mathrm{CaO}$ in slag decreases rapidly. Thus the ratio of $\mathrm{CaS}$ activity to $\mathrm{CaO}$ activity is much larger than that of mass fraction. In this calculation process, the activity of $\mathrm{CaO}$ was total $\mathrm{CaO}$, not free $\mathrm{CaO}$. If the content of 
free $\mathrm{CaO}$ is $5 \%$ of the total $\mathrm{CaO}$, the calculated value is increased by 20 times. This is the reason why the experimental value is larger than the calculated value in Figure 9, but they share the same trend.
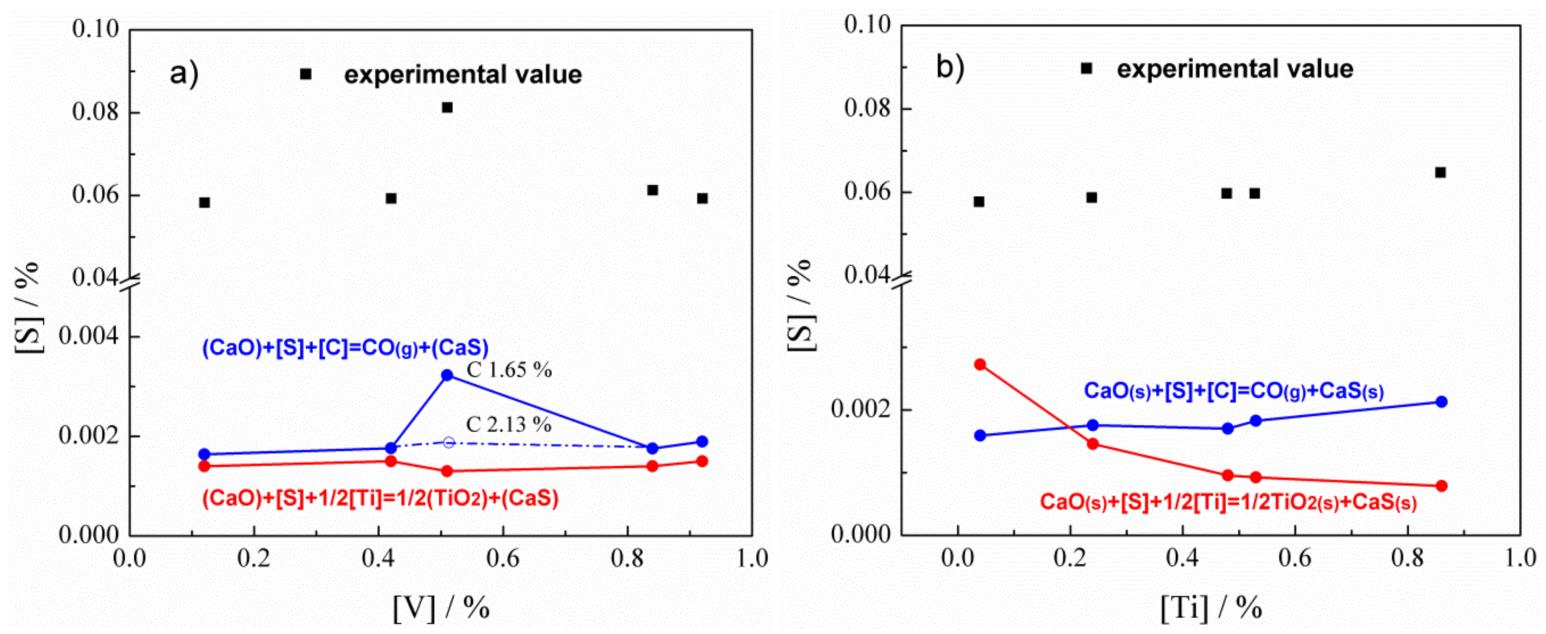

Figure 9. Sulfur content with the change of (a) vanadium and (b) titanium.

According to Table 7, vanadium reduces the activity of sulfur and carbon. Since vanadium has a small weakening effect on activity coefficient and a small variation range of content, it has little influence on the two desulfurization reactions in Figure 9a.

\subsection{Kinetics Perspective}

In the initial stage after adding $\mathrm{CaO}$ powder, the contact interface between solid $\mathrm{CaO}$ particles and liquid iron has a sulfur/oxygen concentration gradient, as is shown in Figure 10. The following reaction occurs:

$$
\begin{gathered}
\mathrm{CaO}(\mathrm{s})=\mathrm{Ca}^{2+}+\mathrm{O}^{2-} \\
\mathrm{O}^{2-}-2 \mathrm{e}^{-}=[\mathrm{O}] \\
{[\mathrm{S}]+2 \mathrm{e}^{-}=\mathrm{S}^{2-}} \\
\mathrm{S}^{2-}+\mathrm{Ca}^{2+}=\mathrm{CaS}(\mathrm{s})
\end{gathered}
$$

On the surface of $\mathrm{CaO}$, dissolved sulfur atoms exchange electrons with oxygen ions. The sulfur atoms that obtain electrons become $\mathrm{S}^{2-}$, which combines with the remaining $\mathrm{Ca}^{2+}$ to form $\mathrm{CaS}(2673 \mathrm{~K}$ of melting point). After losing electrons, oxygen ions become oxygen atoms and dissolve into liquid iron. [O] reacts with [C] and [Ti] in liquid iron to form $\mathrm{CO}$ gas or $\mathrm{TiO}_{2}(2123 \mathrm{~K}$ of melting point). With the continuous exchange of sulfur and oxygen, $\mathrm{CaS}$ intersperses on the surface of $\mathrm{CaO}$ particles and penetrates into $\mathrm{CaO}$ particles gradually. For the liquid iron with high titanium, $\mathrm{TiO}_{2}$ that was generated by [Ti] and [O] attaches to the surface of $\mathrm{CaO}$ particles, and then it combines with $\mathrm{CaO}$ to form $\mathrm{CaTiO}_{3}$ (2253 K of melting point), which envelops $\mathrm{CaO}$ and prevents the replacement of sulfur and oxygen gradually. According to the thermodynamic analysis, the combining capacity of vanadium and $[\mathrm{O}]$ in the liquid iron is lower than that of carbon and titanium. Therefore, vanadium does not combine with the oxygen from $\mathrm{CaO}$ to form vanadium oxide which attaches to the surface of $\mathrm{CaO}$. 


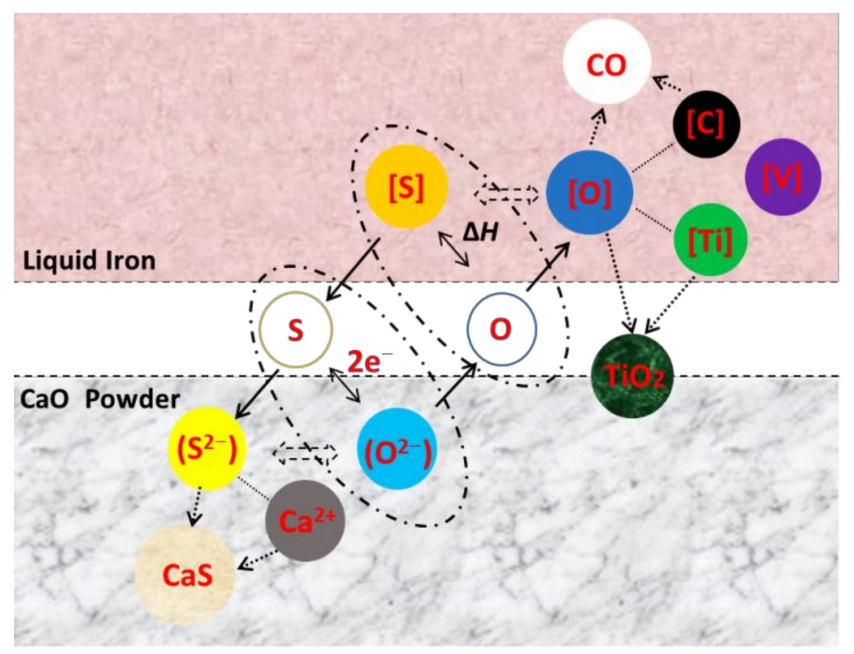

Figure 10. Schematic diagram of $\mathrm{CaO}$ desulfurization reaction.

Due to the high sulfur content in liquid iron, the desulfurization velocity is controlled by the diffusion of sulfur through the reactant layer to the interior of $\mathrm{CaO}$ particles. At this time, a large amount of $\mathrm{CaO}$ particles could touch the surface of liquid iron and react with sulfur quickly. $\mathrm{TiO}_{2}$ generated on the surface of $\mathrm{CaO}$ hinders the desulfurization reaction, which is the reason for the slow desulfurization velocity of high titanium content. During this period, the vanadium does not have a great influence on the desulfurization velocity.

At the later stage of desulfurization, solid $\mathrm{CaO}$ is dissolved in the liquid slag. The reaction changes to:

$$
\left(\mathrm{O}^{2-}\right)+[\mathrm{S}]=\left(\mathrm{S}^{2-}\right)+[\mathrm{O}]
$$

Under this experimental condition, the liquid iron has relatively large viscosity. The desulfurization velocity is controlled by the mass transfers of [S] in liquid iron $[25,26]$. The equation is as follows:

$$
-\frac{d[\% S]}{d t}=\frac{A}{V_{m}} k_{[S]}\left([\% S]-[\% S]^{e}\right)
$$

where $A$ is the superficial area of the interface, $V_{m}$ is the volume of the liquid iron, $k_{[S]}$ is the mass transfer coefficient of sulfur in the liquid iron, $[\% S]$ and $[\% S]^{e}$ are the mass percent of $[S]$ in the metal and in the slag/iron interface, respectively.

The $k_{[S]}$ is directly proportional to temperature and inversely proportional to the viscosity of liquid iron [27-29]. The viscosity of liquid iron increases with the content of vanadium and titanium [7]. Hence, a higher content of vanadium and titanium reduces the velocity of desulfurization. On the other hand, the combination of $\mathrm{CaO}$ and other oxides leads to a reduction in free $\mathrm{CaO}$, and the desulfurization velocity decreases gradually.

As there are insufficient conditions for vanadium to combine with oxygen from $\mathrm{CaO}$ to form vanadium oxide, the desulfurization effect of vanadium is not as good as that of titanium.

\section{Conclusions}

The top slag has some beneficial effect on hot metal desulphurization. However, its effect is not as good as that of the desulfurizing agent.

Titanium in liquid iron had a certain influence on the desulfurization of adding $\mathrm{CaO}$. In the range of desulphurization temperatures, $\mathrm{TiO}_{2}$ was generated by the reaction of titanium with oxygen from $\mathrm{CaO}$. Then, it attached to the surface of $\mathrm{CaO}$ powder. For small $\mathrm{CaO}$ particles, the oxygen displaced by sulfur reacted with carbon to form $\mathrm{CO}$ gas and escape. The oxides of iron, calcium, and titanium were mixed together on the top of the liquid iron, and calcium sulfide was dispersed in the oxides. 
The higher the titanium content, the lower the desulfurization velocity. Under low sulfur conditions, the titanium element no longer participated in $\mathrm{CaO}$ desulfurization reaction. The change of vanadium and titanium contents had little effect on the final sulfur content, while the change of carbon content had a great influence on the final sulfur content.

Therefore, the influence of vanadium and titanium on desulfurization is not the main reason why the effect of semi-steel desulfurization is better than that of hot metal in field production. It is most likely due to the desulfurization temperature and the composition of the desulfurization agent, which will be the research in the next stage.

Author Contributions: Conceptualization, B.Y.; methodology, B.Y., B.S., and L.L.; validation, B.S.; formal analysis, B.Y. and L.L.; investigation, B.Y. and L.C.; resources, B.S. and L.C.; data curation, B.S. and B.Y.; writing-original draft preparation, B.Y.; writing—review and editing, B.Y., B.S., L.L., and L.C.

Funding: This research received no external funding.

Acknowledgments: Thanks to Hu Yihang for his language help and PanGang Group for the donation of vanadium slag.

Conflicts of Interest: The authors declare no conflict of interest.

\section{References}

1. Mukawa, S.; Ueshima, Y.; Sano, M.; Yang, J.; Kuwabara, M. The effect of magnesium gas injecting conditions on the rate of hot metal desulfurization. ISIJ Int. 2006, 46, 1778-1782. [CrossRef]

2. Kikuchi, N.; Nabeshima, S.; Kishimoto, Y. Effect of propane gas on hot metal desulfurization by CaO based flux. ISIJ Int. 2012, 52, 1809-1816. [CrossRef]

3. Matsui, A.; Uchida, Y.-I.; Kikuchi, N.; Miki, Y. Effects of temperature and oxygen potential on removal of sulfur from desulfurization slag. ISIJ Int. 2017, 57, 1012-1018. [CrossRef]

4. Ge, W.S.; Gong, H.J.; Jiang, L.K.; Li, L.; Chen, L. Study on process optimization of the vanadium containing hot metal pretreatment. In Advanced Materials Research; Trans Tech Publication: Zurich, Switzerland, 2013; pp. 2389-2392.

5. Guangyuan, W. Pretreatment of the hot iron containing vanadium and titanium. J. Chongqing Univ. Nat. Sci. Ed. 1993, 22, 113-120.

6. Donahue, F.M.; Pehlke, R.D. Equilibrium between sulfur and titanium in liquid iron. Metall. Mater. Trans. B 1987, 18, 681-685. [CrossRef]

7. Wen, G.; Yan, Y.; Zhao, S.; Huang, J.; Jiang, G.; Yang, X. Properties of liquid iron containing vanadium and titanium. Iron Steel 1996, 31, 6-11.

8. Cheng, C.; Dou, Z.H.; Zhang, T.A.; Su, J.M.; Zhang, H.J.; Liu, Y.; Niu, L.P. Sulfur distribution in preparation of high titanium ferroalloy by thermite method with different $\mathrm{CaO}$ additions. Rare Met. 2019, 38, 793-799. [CrossRef]

9. Visser, H.-J.; Boom, R. Advanced process modelling of hot metal desulphurisation by injection of $\mathrm{Mg}$ and CaO. ISIJ Int. 2006, 46, 1771-1777. [CrossRef]

10. Bouchard, D.; Bale, C.W. Simultaneous optimization of thermochemical data for liquid iron alloys containing C, N, Ti, Si, Mn, S, and P. Metall. Mater. Trans. B 1995, 26, 467-484. [CrossRef]

11. Lindström, D.; Sichen, D. Study on desulfurization abilities of some commonly used desulfurization agents. Steel Res. Int. 2015, 86, 73-83. [CrossRef]

12. Lindström, D.; Sichen, D. Kinetic study on desulfurization of hot metal using $\mathrm{CaO}$ and $\mathrm{CaC}_{2}$. Metall. Mater. Trans. B 2015, 46, 83-92. [CrossRef]

13. Ohta, H.; Suito, H. Activities of $\mathrm{SiO}_{2}$ and $\mathrm{Al}_{2} \mathrm{O}_{3}$ and activity coefficients of FetO and $\mathrm{MnO}$ in $\mathrm{CaO}-\mathrm{SiO}_{2}-\mathrm{Al}_{2} \mathrm{O}_{3}-\mathrm{MgO}$ slags. Metall. Mater. Trans. B 1998, 29, 119-129. [CrossRef]

14. Condo, A.-F.-T.; Lindström, D.; Sichen, D. Study on the equilibrium of slag and hot metal at tapping with respect to sulfur. Steel Res. Int. 2017, 88, 1600336. [CrossRef]

15. Kitamura, S.Y. Hot metal pretreatment. Treatise Process Metall. 2014, 3, 177-220.

16. Dong, Y.; Selin, R. Activity of components in Fe-C-S and Fe-C-P ternary melts. J. Iron Steel Res. 1991, 3, 9-16.

17. Chen, E.-B.; Wang, S.-J.; Zhou, Y.; Wu, B.-G. Activity interaction coefficients in Fe-C-N, Fe-C-V and Fe-C-V-N Melts. Chin. J. Process Eng. 2005, 5, 529-531. 
18. Wang, H.; Wang, S.; Yue, K.; Dong, Y. The rules of thermodynamic properties in Fe-C-j (j=Ti,V,Cr,Mn) melts. Acta Met. Sin. 2001, 37, 952-956.

19. Zhang, J.Y. Phys. Chemi. Metall., 1st ed.; Metallurgical Industry Press: Beijing, China, 2004.

20. Guo, Y.; Wang, C. Interaction coefficients in Fe-C-Ti-i (i = Si, Cr, AI, Ni) systems. Metall. Trans. B 1990, 21, 543-547.

21. Zhang, J.; Lv, X.; Yan, Z.; Qin, Y.; Bai, C. Desulphurisation ability of blast furnace slag containing high $\mathrm{Al}_{2} \mathrm{O}_{3}$ and 5 mass $\% \mathrm{TiO}_{2}$ at $1773 \mathrm{~K}$. Ironmak. Steelmak. 2016, 43, 378-384. [CrossRef]

22. Turkdogan, E.; Leake, L. Thermodynamics of carbon dissolved in iron alloys. Part I: Solubility of carbon in iron-phosphorus, iron-silicon, and iron-manganese melts. J. Iron Steel Inst. Lond. 1955, 179, 39-43.

23. Chen, E.B.; Dong, Y.C.; Guo, S.X. Activity interaction coefficients in Mn-Fe-C melts. Chin. J. Process Eng. 2003, 3, 335-339.

24. Wu, P.; Yang, Y.; Barati, M.; Mclean, A. Thermodynamic and kinetic aspects of sulfur evaporation from Fe-C alloy droplets. ISIJ Int. 2015, 55, 717-722. [CrossRef]

25. Tong, Z.; Qiao, J.; Jiang, X. Hot metal desulfurization kinetics by $\mathrm{CaO}-\mathrm{Al}_{2} \mathrm{O}_{3}-\mathrm{SiO}_{2}-\mathrm{MgO}-\mathrm{TiO}_{2}-\mathrm{Na}_{2} \mathrm{O}$ slags. ISIJ Int. 2017, 57, 245-253. [CrossRef]

26. Nakai, Y.; Hino, Y.; Sumi, I.; Naoki, K.; Yuichi, U.; Yuji, M. Effect of flux addition method on hot metal desulfurization by mechanical stirring process. ISIJ Int. 2015, 55, 1398-1407. [CrossRef]

27. Zhang, J.-Z.; Yang, Y.; Fan, W.; Zhang, J.; Yi, Z. Experimental determination of sulfur partition ratio in the $\mathrm{CaO}-\mathrm{Al}_{2} \mathrm{O}_{3}-\mathrm{SiO}_{2}-\mathrm{CaF}_{2}-\mathrm{MgO}$ slag and liquid iron. In IOP Conference Series: Materials Science and Engineering; IOP Publishing: Bristol, UK, 2017.

28. Zhang, K.; Zhang, Y.; Wu, T. Kinetics of hot metal desulfurization using $\mathrm{CaO}-\mathrm{SiO}_{2}-\mathrm{Al}_{2} \mathrm{O}_{3}-\mathrm{Na}_{2} \mathrm{O}-\mathrm{TiO}_{2}$ slag. J. Iron Steel Res. Int. 2019, 26, 1041-1051. [CrossRef]

29. Yang, A.-F.; Karasev, A.; Jönsson, P.-G. Characterization of metal droplets in slag after desulfurization of hot metal. ISIJ Int. 2015, 55, 570-577. [CrossRef]

(C) 2019 by the authors. Licensee MDPI, Basel, Switzerland. This article is an open access article distributed under the terms and conditions of the Creative Commons Attribution (CC BY) license (http://creativecommons.org/licenses/by/4.0/). 